\title{
PEMBERDAYAAN MASYARAKAT MELALUI PROGRAM KELUARGA HARAPAN (PKH) DI KELURAHAN RANOTANA WERU
}

\author{
Jael Murib \\ Oktavianus Porajow \\ Lorraine W. Th. Sondak
}

\begin{abstract}
This study aims to describe Community Empowerment through Hope Family Program in Ranotana Weru Village, Wanea Sub-district, Manado City. The data collected consists of primary and secondary. The data used in this study is qualitative, by selecting the village head, the head of the environment, the accompaniment of the Hope Family Program and the beneficiaries as informants. The results of this study prove that, the empowerment done by the government to the poor in Ranotana Weru Village is very good in terms of household needs, health and education. Based on the results of this study can be concluded that; The recipient of the Hope Family Program in Kelurahan Ranotana Weru consists of eight families. Assistance in the form of Direct Cash Assistance to participants maintains the life of basic needs of the household. Community Empowerment through Family Hope Program in Kelurahan Ranotana Weru is not right on target from the main goal of Family Hope Program. Because the benefits by participants of Family Hope Program in ranotana weru sub-district mostly use is household basic need compared to education and health.
\end{abstract}

Keywords: community empowerment, program of family hope, Urban Village of Ranotana Weru.

\begin{abstract}
ABSTRAK
Penelitian ini bertujuan untuk mendeskripsikan Pemberdayaan Masyarakat Melalui Program Keluarga Harapan di Desa Ranotana Weru, Kecamatan Wanea Kota Manado. Data yang dikumpulkan terdiri dari primer dan sekunder. Data yang digunakan dalam penelitian ini adalah kualitatif, dengan memilih kepala desa, kepala lingkungan, pendamping Program Keluarga Harapan dan peserta penerima manfaatnya sebagai informan. Hasil penelitian ini membuktikan bahwa, pemberdayaan yang dilakukan oleh pemerintah kepada masyarakat miskin di Desa Ranotana Weru adalah sangat baik segi dari keperluan rumah tangga, kesehatan dan pendidikan. Berdasarkan dari hasil penelitian ini dapat disimpulkan bahwa; Penerima Program Keluarga Harapan di Kelurahan Ranotana Weru terdiri dari delapan keluarga. Bantuan bersifat Bantuan Langsung Tunai kepada peserta mempertahankan kehidupan kebutuhan dasar rumah tangga. Pemberdayaan Masyarakat Melalui Program Keluarga Harapan di Kelurahan Ranotana Weru tidak tepat pada sasaran dari tujuan utama Program Keluarga Harapan. Karena manfaat oleh peserta Program Keluarga Harapan di kelurahan ranotana weru paling banyak gunakan adalah kebutuhan pokok rumah tangga dibandingkan pendidikan dan kesehatan.
\end{abstract}

Kata kunci: pemberdayaan masyarakat, program keluarga harapan, Kelurahan Ranotana Weru. 


\section{PENDAHULUAN}

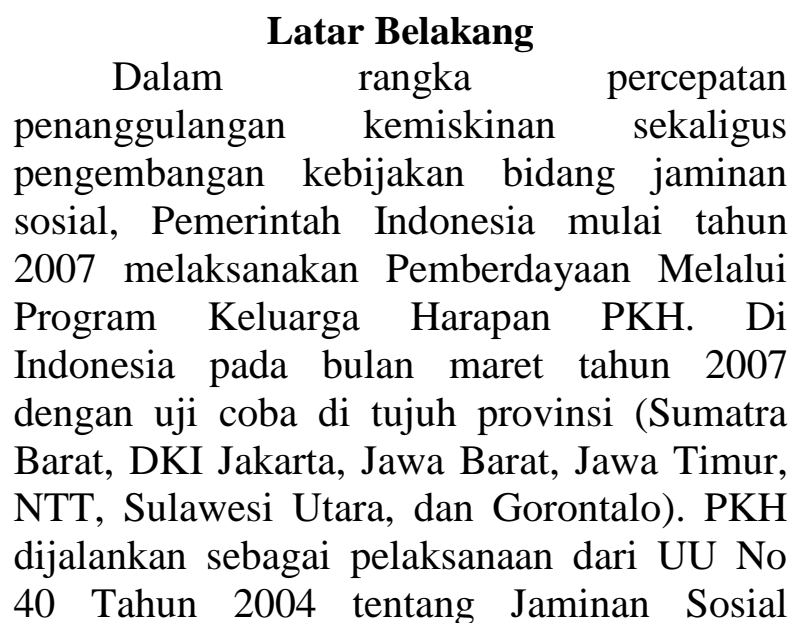
Nasional, UU No 11 Tahun 2009 tentang Kesejahteraan Social UU No 39 Tahun 1999 tentang Hak Asasi Manusia, Intruksi Presiden No 3 Tahun 2010 tentang Rencana Tindak Percepatan Pencapaian Sasaran Program ProRakyat, dan peraturan Presiden No 15 Tahun 2010 tentang Percepatan Penaggulangan Kemiskinan. PKH merupakan bantuan sosial yang dimaksudkan demi mempertahankan kehidupan dalan kebutuhan dasar.

Pelaksanaan PKH secara berkesinambungan setidaknya hingga tahun 2015 akan mempercepat pencapaian Tujuan Pembangunan Milenium (Millennium Development Goals atau MDGs). Setidaknya terdapat 5 komponen (MDGs) yang akan dicapai oleh $\mathrm{PKH}$, yaitu pengurangan penduduk miskin dan kelaparan, pendidikan dasar, kesetaraan gender, pengurangan angka kematian bayi dan balita, dan pengurangan kematian ibu melahirkan.

Dalam PKH, bantuan diberikan kepada rumah tangga sangat miskin (RTSM) dengan persyaratan yang dikaitkan dengan upaya peningkatan sumberdaya manusia seperti pendidikan, kesehatan dan gizi. Untuk jangka pendek, bantuan ini akan membantu beban pengeluaran RTSM. Sedangkan untuk jangka panjang, dengan mensyaratkan keluarga penerima untuk menyekolahkan anaknya, melakukan imunisasi balita, memeriksakan kandungan bagi ibu hamil, dan perbaikan gizi, diharapkan akan memutus rantai kemiskinan antar generasi.
Walikota Manado GS Vicky Lumentut, melalui Wakil Walikota Bastiaan menghadiri sekaligus memberikan sambutan dalam acara penyaluran bantuan non tunai dari Kementerian Sosial Republik Indonesia Program Keluarga Harapan. Jumat (04/08/2017) di Kantor Kecamatan Mapanget, Kota Manado. Wakil Walikota mengatakan bahwa dalam jangka pendek program ini bertujuan untuk mengurangi beban rumah tangga sangat miskin (RTSM), dan dalam jangka panjang diharapkan dapat memutus mata rantai kemiskinan antar generasi, sehingga generasi berikutnya bisa keluar dari perangkap kemiskinan.

Lanjut dikatakan, komponen yang menjadi fokus utama dari PKH adalah bidang kesehatan dan pendidikan, di mana tujuan utama bidang kesehatan untuk meningkatkan status kesehatan ibu dan anak di Indonesia, khususnya bagi kelompok masyarakat sangat miskin melalui pemberian insentif untuk melakukan kunjungan kesehatan yang bersifat preventif atau pencegahan.

"Kita semua berharap PKH terlebih khusus di Kota Manado dapat dilaksanakan dan disalurkan dengan tepat sasaran dan tepat guna, dan melalui penyerahan bantuan non tunai dari Kemensos RI PKH tahap satu tahun 2017 ini, upaya peningkatan kualitas sumber daya manusia diharapkan dapat berjalan dengan efektif dan berhasil guna demi kesejahteraan masyarakat Kota Manado," ujar Wakil Walikota.

\section{Perumusan Masalah}

Berdasarkan latar belakang masalah yang dikemukakan diatas maka yang menjadi permasalahan adalah bagaimana Pemberdayaan Masyarakat Melalui Program Keluarga Harapan di Kelurahan Ranotana Weru.

\section{Tujuan Penelitian}

Tujuan dari penelitian ini, yaitu untuk mendeskripsikan Pemberdayaan Masyarakat Melalui Program Keluarga Harapan PKH di Kelurahan Ranotana Weru. 


\section{Manfaat Penelitian}

Yang menjadi manfaat dalam penelitian ini adalah 1, Bagi masyarakat miskin sebagai pelaku utama. Hasil penelitian ini diharapkan dapat digunakan sebagai informasi dan bahan pertimbangan di kelurahan ranotana weru. 2, Instansi Urusan Badan Pemberdayaan Masyarakat BPM diharapkan dapat menjadi masukan. Pemberdayaan Masyarakat Melalu PKH di Kelurahan Ranotan Weru. 3, Bagi pihak yang berkompeten diharapkan dapat menjadi informasi dalam membangun koordinasi yang harmonis dalam Pemberdayaan Masyarakat Melalui PKH Di Kelurahan Ranotana Weru.

\section{METODOLOGI PENELITIAN}

\section{Waktu dan Tempat/Lokasi Penelitian}

Tempat/lokasi penelitian ini, lakukan di Provinsi Sulawesi Utara, Kabupaten/Kota Manado Kecamatan Wanea, Kelurahan Ranotana Weru. Selama tiga bulan yaitu dari bulan Oktober sampai bulan Desember 2017.

\section{Jenis Dan Sumber Data}

Jenis dan sumber data yang dipakai dalam penelitian ini adalah: Pertama, data primer diperoleh melalui wawancara langsung kepada responden dengan menggunakan kuesioner yang telah disiapkan oleh penelitih. Kedua, data sekunder diperoleh melalui Kantor Desa tempat penelitihan, (Instansi terkait).

\section{Metode Pengambilan Sampel}

Populasi Program Keluarga Harapan di Kelurahan Ranotana Weru terdiri dari 10 kepala lingkungan, keseluruhan penerima $\mathrm{PKH}$ adalah delapan keluarga, yang dilingkungan II, 1 keluarga. Lingkungan III, 4 keluarga dan lingkungan IV, 3 keluarga. Keseluruhan yang diambil dalam penelitian ini yaitu delapan keluarga, di III lingkungan satu kelurahan.

\section{Metode Pengumpulan Data}

Metode pengambilan data secara purposive sampling, di Kelurahan Ranotana Weru lingkungan II, III dan IV.

\section{Konsep Pengukuran Variabel}

Variabel dalam penelitian ini, adalah jumlah masyarakat penerima bantuan PKH di Kelurahan Ranotana Weru Lingkungan II, III dan IV. Dan jenis bantuan Program Keluarga Harapan, yaitu bantuan langsung tunai BLT.

\section{Metode Analisis Data}

Analisis data yang digunakan dalam penelitian ini yaitu analisis deskriptif dan data bentuk tabel, kemudian dideskripsikan.

\section{HASIL DAN PEMBAHASAN}

\section{Deskripsi Lokasi Penelitian}

Ranotana Weru, merupakan salah satu kelurahan yang berada di Kecamatan Wanea Kota Manado Provinsi Sulawesi Utara, Kelurahan Ranotana Weru yang terdiri dari satu kelurahan 10 kepala lingkungan terletak di dataran rendah berdekatan dengan pasar karombasan 800 meter. Kelurahan Ranotana Weru memiliki perbatasan antar keluarahan dibagian timur ke barat dan utara ke selatan yaitu; Pertama, Bagian barat dengan nama Kelurahan Karombasan Uatara. Kedua, Bagian timur perbatasan kabupaten minahasa uatara. Ketiga, bagian utara Kelurahan Pakowa dan yang keempat, bagian selatan Kelurahan Karombasan Selatan. Berikut adalah peta lokasi Kecamatan Wanea, Kelurahan Ranotana Weru.

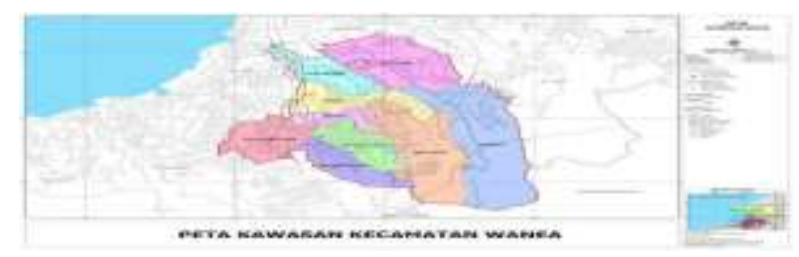

Gambar 1. Peta Kecamatan Wanea Kelurahan Ranotana Weru Sumber : Kelurahan Ranotana Weru

\section{Jumlah Penduduk Di Kelurahan Ranotana Weru}

Jumlah penduduk di Kelurahan Ranotana Weru Pemerintah Kota Manado Kecamatan Wanea secara keseluruhan jumlah penduduk adalah 7916 jiwa, masing-masing menurut jenis kelamin 10 Lingkungan di Kelurahan Ranotana Weru akan disusun dalam Tabel berikut ini. 
Tabel 1. Jumlah Penduduk di Kelurahan Ranotana Weru Menurut Lingkungan dan Jenis Kelamin

\begin{tabular}{|c|c|c|c|c|c|}
\hline \multirow[t]{2}{*}{ No. } & \multirow[t]{2}{*}{ Lingkungan } & \multirow{2}{*}{$\begin{array}{c}\text { Jumlah } \\
\text { KK }\end{array}$} & \multicolumn{2}{|c|}{$\begin{array}{c}\text { Jumlah } \\
\text { Penduduk }\end{array}$} & \multirow[t]{2}{*}{ Jumlah } \\
\hline & & & $\mathrm{L}$ & $\mathrm{P}$ & \\
\hline 1 & Lingkungan I & 196 & 346 & 301 & 843 \\
\hline 2 & Lingkungan II & 169 & 268 & 251 & 688 \\
\hline 3 & Lingkunagn III & 169 & 229 & 251 & 626 \\
\hline 4 & Lingkungan IV & 203 & 349 & 373 & 925 \\
\hline 5 & Lingkungan V & 146 & 273 & 256 & 675 \\
\hline 6 & Linkungan VI & 127 & 209 & 206 & 542 \\
\hline 7 & Lingkungan VII & 138 & 265 & 246 & 649 \\
\hline 8 & Lingkungan VIII & 160 & 252 & 251 & 663 \\
\hline 9 & Lingkungan IX & 215 & 478 & 488 & 1181 \\
\hline 10 & Lingkungan X & 261 & 507 & 356 & 1124 \\
\hline Total & & 1761 & 3176 & 2979 & 7916 \\
\hline
\end{tabular}

Sumber : Kelurahan Ranotana Weru

\section{Agama}

Dalam kehidupan umat beragama di Kelurahan Ranotana Weru Kecamatana Wanea di jamin kebebasannya dalam UUD 1945 pada pasal 29 yang menyatakannya bahwa Negara berdasarkan asas ideology pancasila dan sila pertama, "Ketuhanan Yang Maha Esa" adalah untuk menunjang kebutuhan beragama membangun tempat peribadaan seperti, Gereja, Mesjid dan lainlain. Teruma pada hari-hari besar keagaman. Adapun jumlah rumah ibadah menurut golongan agama dapat dirinci dalam tabel berikut:

Tabel 2. Jumlah Sarana Tempat Ibadah

\begin{tabular}{lllc}
\hline No. & \multicolumn{1}{c}{ Agama } & Tempat Ibadah & Jumlah \\
\hline 1 & Islam & Mesjid & 1 \\
2 & Kristen Protestan & Gereja & 9 \\
3 & Kristen Katolik & Gereja & 0 \\
4 & Hindu & Vihara & 0 \\
5 & Budha & Pura & 0 \\
\hline & Total & $\mathbf{1 0}$ \\
\hline
\end{tabular}

Sumber : Kelurahan RanotanaWeru

Tabel 2, memberikan gambaran bahwa penduduk Kelurahan Ranotana Weru didominasi oleh umat Beragama Kristen Protestan yakni 90\% dari total penduduk dan tempat ibadah umat Kristen Protestan adalah yang lebih banyak dibandingkan dengan umat beragama lainnya.

\section{Pendidikan}

Berbagai upaya telah dilakukan, baik oleh pemerintah maupun masyarakat dalam meningkatkan sumber daya manusia (SDM) di Kelurahan Ranotana Weru, khusus dari aspek pendidikan baik melalui formal dan informal. Sarana pendidikan formal yang ada di Kelurahan Ranotana Weru terdiri dari : lima unit TK, tiga unit SD, satu unit SMP, satu unit SMA dan Perguruan Tinggi kosong.

\begin{tabular}{llc}
\multicolumn{2}{l}{ Tabel 3. Sarana Pendidikan } \\
\hline No. & Sekolah & Jumlah (Unit) \\
\hline 1 & TK & 5 \\
2 & SD & 3 \\
3 & SMP & 1 \\
4 & SMA & 1 \\
5 & Perguruan Tinggi & 0 \\
\hline & Jumlah & $\mathbf{1 0}$
\end{tabular}

Sumber : Pemerintah Kecamatan Wanea Kelurahan Ranotana Weru

Tabel 3. Menunjuhkan bahwa, sarana pendidikan yang tidak ada di Kelurahan Ranotana Weru adalah Perguruan Tinggi.

\section{Penerima Bantuan PKH di Kelurahan Ranotana Weru}

Penerima bantuan PKH di Keluarahan Ranotana Weru adalah delapan keluarga, bantuan PKH ini diserahkan dalam satu tahun kepada setiap peserta yaitu, Rp.1.850.000 perkepala keluarga, bantuan tersebut diserahkan dalam empat tahapan. Tahap pertama bulan yang ke tiga, tahap kedua bulan yang keenam, tahap ketiga bulan yang ke sembilan dan tahap keempat bulan yang keduabelas. Masing-masing bulan, jumlah total bantuan PKH yang menerima oleh keluaraga adalah; Pertama bulan ketiga Rp.500.000 kedua bulan keenam Rp.500.000 ketiga bulan kesembilan Rp.500.000 keempat bulan kedua belas Rp.350.000.

\begin{tabular}{lccc} 
Tabel & $\begin{array}{c}\text { 4. Penerima Bantuan PKH di Kelurahan Ranotana } \\
\text { Weru }\end{array}$ & \multicolumn{2}{c}{} \\
\hline No. & Lingkungan & $\begin{array}{c}\text { Jumlah } \\
\text { Penerima }\end{array}$ & $\begin{array}{c}\text { Jumlah } \\
\text { Diterima }\end{array}$ \\
\hline 1 & & 1 & 1.850 .000 \\
2 & II & 4 & 7.400 .000 \\
3 & III & 3 & 5.550 .000 \\
\hline Total & $\mathbf{3}$ & $\mathbf{8}$ & $\mathbf{1 4 . 8 0 0 . 0 0 0}$ \\
\hline Sumber : Pendamping PKH dan Peserta PKH di Kelurahan \\
\multicolumn{4}{l}{ Ranotana Wru }
\end{tabular}

Tabel 4. Adalah memberikan gambaran bahwa, keluarga penerima manfaat PKH di Ranotana Weru adalah delapan keluarga. Lingkungan II, satu keluarga. Lingkungan III, empat keluarga dan lingkungan IV, tiga keluarga. 


\section{Manfaat PKH di Lingkungan II}

Manfaat PKH di lingkungan II adalah sebagai salah satu program yang dayakan atau membantu dalam rumah tangga untuk kebutuhan kehidupan dasar di Kelurahan Ranotana Weru, PKH bantuan langsung tunai BLT kepada keluarga penerima bantuan untuk meningkatkan kemampuan pekerja orang tua yang sangat ekonomi lemah. Program Keluarga Harapan merupakan salah satu program yang mensejahterakan masyarakat berangkat dari kurangnya pendapatan orang tua dalam rumah tangga atau ekonomi lemah di Kelurahan Ranotana Weru Lingkungan II, untuk menigkatkan pendapatan orang tua sehari-hari dalam konsumsi dan peralatan keperluan rumah tangga. Manfaat yang digunakan keluarga melalui PKH di Kelurahan Ranotan Weru Lingkungan II, yaitu: 1. Keperluan rumah tangga, diberikan melalui BLT, untuk digunakan dalam keperluan rumah tangga. Contoh: bayar listrik, peralatan dapur, dan keperluan lainnya. 2. Kesehatan, dalam tahapan PKH di kelurahan Ranotana Weru Lingkungan II menyangkut kesehatan adalah, diberikan kartu jaminan BPK badan pelayanan kesehatan, hanya dikhususkan pada keluarga peserta PKH. 3. Pendidikan, dalam hal ini diberikan biaya kepada keluarga peserta PKH untuk pembajaran SPP di sekolah adalah satu anak perempuan berumur 12 tahun sedang dibangku SMA. 4. Bahan makanan diberikan dalam tahapan akhir bulan dalam satu tahun, bersifat makanannya yaitu beras $20 \mathrm{kl}$ dua karung.

\section{Manfaat PKH di Lingkungan III}

Manfaat melalu PKH dilignkungan III Kelurahan Ranotana Weru adalah sebagai salah satu faktor yang membantu dalam rumah tangga yang sangat miskin di Kelurahan Ranotana Weru. Dengan adanya PKH BLT kepada keluarga yang sangat miskin untuk meningkatkan kemampuan pekerja orang tua yang sangat miskin dalam ekonom. PKH merupakan salah satu program yang mensejahterakan masyarakat berangkat dari kurangnya pendapatan orang tua dalam rumah tangga. dikelurahan ranotana weru lingkungan III, untuk menigkatkan pendapatan orang tua sehari-hari dalam konsumsi dan peralatan keperluan rumah tangga. Manfaat yang digunakan melalui PKH di Kelurahan Ranotana Weru lingkungan III yaitu : 1. Perlengkapan rumah tangga RT, yaitu membajar listrik, air pam, sabun cuci, sabon mandi, minyak gass, minyak tanah dan kebutuhan sehari-hari. 2. Pendidikan, biaya dan kelengkapan anak-anak sekolah. 3. Ibu hamil, yaitu awal memulai kehamilan sampai dengan persalinan untuk keselamatan anak-anak bayi dalam kehamilan.

\section{Manfaat PKH Di Lingkungan IV}

Manfaat melalui PKH di Kelurahan Ranotana Weru Lignkungan IV adalah sebagai salah faktor yang mendorong dalam Rumah Tangga RT yang sangat miskin di Kelurahan Ranotana Weru Linkungan IV. Dengan adanya PKH bantuan langsung tunai kepada keluarga yang sangat miskin untuk meningkatkan kemampuan pekerja orang tua yang sangat miskin dalam ekonomi. PKH merupakan salah satu program yang mensejahterakan masyarakat berangkat dari kurangnya pendapatan orang tua dalam rumah tangga di Kelurahan Ranotana Weru lingkungan IV, untuk menigkatkan pendapatan orang tua sehari-hari dalam konsumsi dan peralatan keperluan rumah tangga. Program ini diupayakan khusus kepada rumah tangga yang sangat miskin RTSM untuk memutuskan rantai kemiskinan. Manfaat yang digunakan melalui PKH di kelurahan ranotan weru lingkungan IV adalah tiga keluarga dan masing-masing penyelasan dalam penggunaan PKH adalah sebagai berikut: 1. "Responden 6" keluarga ini bersifat bantuan BLT, manfaat PKH dalam keluarga ini yaitu, bahan makanan seharihari dan kebutuhan lainnya dalam rumah tangga. 2. "Responden 7" keluarga ini bersifat bantuannya BLT, dan penggunaan yaitu perlengkapan rumah tangga, dan keperluan lainnya dalam keluarga. 3 . "Responden 8" bersifat bantuan BLT, dan penggunaannya yaitu keperluan rumah tangga, biaya anak sekolah dan keperluan lainnya. Tujuan umum dalam keluarga penerima manfaat Program Keluarga Harapan di Kelurahan Ranotana Weru Lingkungan IV, yaitu; 1. Perlengkapan rumah tangga RT, yaitu membajar listrik, air pam, sabun cuci, sabun mandi, gas, minyak tanah, dll. 2. Perlengkapan anak-anak sekolah, yaitu buku tulis, bolpen atau pensil, tas sekolah, pakaian sekolah dan biaya sekolah. 3. Bahan makanan, yaitu beras, sayursayuran, ikan, buah-buahan dan air minum. 4. Ibu hamil, yaitu awal memulai kehamilan sampai dengan persalinan untuk keselamatan anak-anak 
bayi dalam kehamilan khusus yang menerima PKH. 5. Kesehatan, yaitu saat keluarga tersebut mengalami kesakitan.

Dalam PKH ini, yang paling banyak manfaat adalah Bantua Langsung Tunai BLT, di lingkungan IV. dibandingkan kesehatan dan pembiayaan pendidikan yaitu seketika dibutuhkan oleh penerima bantuan PKH tersebut.

\section{KESIMPULAN DAN SARAN}

\section{Kesimpulan}

Berdasarkan hasil penelitian dapat disimpulkan bahwa; Penerima PKH di Kelurahan Ranotana Weru terdiri dari delapan keluarga. Bantuan ini bersifat BLT kepada peserta mempertahankan kehidupan kebutuhan dasar rumah tangga. Pemberdayaan Masyarakat Melalui Program Keluarga Harapan di Kelurahan Ranotana Weru tidak tepat pada sasaran dari tujuan utama PKH. Karena manfaat oleh peserta PKH di kelurahan ranotana weru paling banyak gunakan adalah kebutuhan pokok rumah tangga dibandingkan pendidikan dan kesehatan.

\section{Saran}

Saran dari penulis sehubungan dengan Pemberdayaan Masyarakat Melalui Program Keluarga Harapan di Kelurahan Ranotana Weru adalah peserta harus lebih bertanggung jawab dalam menjalankan komitmen atau kewajibann sebagai peserta PKH. Manfaat yang didapatkan oleh penerima harus digunakan sebaik-baiknya pada kebutuhan dalam keperluan Rumah Tangga, Pendidikan dan Kesehatan. Untuk, itu penulis juga menyarankan bahwa, melalui bantuan PKH ini semoga bermafaat bagi keluarga ekonomi lemah di Kelurahan Ranotana Weru untuk memutuskan rantai kemiskinan generasi penerus.

\section{DAFTAR PUSTAKA}

Adams R. 2003. Social Work and Empowerment. Palgrave Macmillan. New York.

Adisasmita. 2006. Membangun Desa Partisipatif. Graha Ilmu. Yogyakarta.

Direktorat Jenderal Bantuan dan Jaminan Social, 2009. Pedoman Umum Program Keluarga Harapan. Kementerian Sosial Republik Indonesia, Jakarta.
Sulistyani. 2004. Pemberdayaan Merupakan Penciptaan Suasana Atau Iklim. Jakarta.

Friedman J. 1992. Empowerment The Politics Of Alternative Development. Blackwell. Cambridge.

Jamasy O. 2004. Keadilan, Pemberdayaan dan Penanggulangan Kemiskinan. Blantika. Jakarta.

Kartasasmita G. 1995. Pemberdayaan Masyarakat Sebuah Tinjauan Administrasi. Malang.

Kartasasmita G 1996. Pemberdayaan Masyarakat Konsep Pembangunan Yang Berakar Pada Masyarakat. Institut Teknologi Bandung. Bandung.

Mas"Oed. 1993. Ekonomi Politik Pembangunan dan Pemberdayaan Masyarakat Dalam Prospektif. Vol,5. No 2. Jakarta.

Prijono Onny S. dan A. M. W. Pranarka. 1996. Pemberdayaan Konsep Kebijakan dan Implementasi. Centre for Strategic and International Studies. Jakarta.

Raila Adnin. 2014. Peran Pendamping Dalam Pemberdayaan Masyarakat Miskin Melalui PKH. Bogor.

Risyanti R. dan Roesmidi M. 2006. Pemberdayaan Masyarakat. Sumedang. Alqaprint Jatinangor. Bogor.

Surjono A. dan Trilaksono N. 2008. Paradigma Model Pendekatan Pembangunan dan Pemberdayaan Masyarakat di Era Otonomi Daerah. Bayumedia, Malang.

Suhendra. 2006. Peranan Birokrasi dalam Pemberdayaan Masyarakat. Alfabeta, Bandung.

Sumodiningrat G. 1997. Pemberdayaan Masyarakat. Edisi Kedua. Bina Reka Pariwara. Jakarta.

Sumaryadi I. Nyoman. 2005. Perencanaan Pembangunan Daerah Otonomi dan Pemberdayaan Masyarakat. CV. Citra Utama, Jakarta.

Usman S. 1998. Pembangunan dan pemberdayaan Masyarakat. Pustaka Pelajar. Yogyakarta.

Widjaja H. 2003. Otonomi Desa Merupakan Otonomi Asli Bulat dan Utuh. PT. Raja Grafindo Persada. Jakarta.

Wrihatnolo R. dan Nugroho R. 2007. Manajemen Pemberdayaan Sebuah Pengantar dan Panduan untuk Pemberdayaan Masyarakat. PT Elex Media Komputindo. Jakarta. 